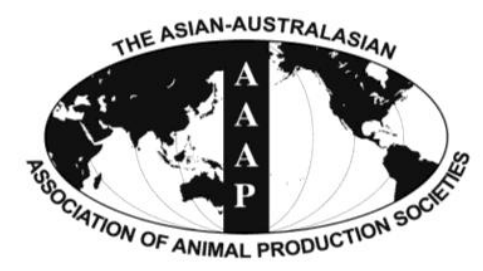

Asian Australas. J. Anim. Sci.

Vol. 26, No. 8 : 1152-1159 August 2013

http://dx.doi.org/10.5713/ajas.2013.13054

www.ajas.info

pISSN $1011-2367$ elSSN 1976-5517

\title{
Effects of Replacing Dry-rolled Corn with Increasing Levels of Corn Dried Distillers Grains with Solubles on Characteristics of Digestion, Microbial Protein Synthesis and Digestible Energy of Diet in Hair Lambs Fed High-concentrate Diets
}

\author{
B. I. Castro-Pérez, J. S. Garzón-Proaño, M. A. López-Soto, A. Barreras, V. M. González,
} A. Plascencia*, A. Estrada-Angulo ${ }^{1}$, H. Dávila-Ramos ${ }^{1}$, F. G. Ríos-Rincón ${ }^{1}$, and R. A. Zinn ${ }^{2}$ Research Institute of Veterinary Sciences, University Autonomous of Baja California, México

\begin{abstract}
Four male lambs (Katahdin; average live weight $25.9 \pm 2.9 \mathrm{~kg}$ ) with "T" type cannulas in the rumen and proximal duodenum were used in a $4 \times 4$ Latin square experiment to evaluate the influence of supplemental dry distillers grain with solubles (DDGS) levels (0, 10, 20 and 30\%, dry matter basis) in substitution for dry-rolled (DR) corn on characteristics of digestive function and digestible energy (DE) of diet. Treatments did not influence ruminal pH. Substitution of DR corn with DDGS increased ruminal neutral detergent fiber $(\mathrm{NDF})$ digestion (quadratic effect, $\mathrm{p}<0.01$ ), but decreased ruminal organic matter $(\mathrm{OM})$ digestion (linear effect, $\mathrm{p}<0.01)$. Replacing corn with DDGS increased (linear, $\mathrm{p} \leq 0.02$ ) duodenal flow of lipids, NDF and feed N. But there were no treatment effects on flow to the small intestine of microbial nitrogen (MN) or microbial $\mathrm{N}$ efficiency. The estimated UIP value of DDGS was $44 \%$. Postruminal digestion of $\mathrm{OM}$, starch, lipids and nitrogen $(\mathrm{N})$ were not affected by treatments. Total tract digestion of $\mathrm{N}$ increased (linear, $\mathrm{p}=0.04)$ as the DDGS level increased, but DDGS substitution tended to decrease total tract digestion of OM $(\mathrm{p}=0.06)$ and digestion of gross energy ( $\mathrm{p}=0.08$ ). However, it did not affect the dietary digestible energy ( $\mathrm{DE}, \mathrm{MJ} / \mathrm{kg}$ ), reflecting the greater gross energy content of DDGS versus DR corn in the replacements. The comparative DE value of DDGS may be considered similar to the DE value of the DR corn it replaced up to $30 \%$ in the finishing diets fed to lambs. (Key Words: Lambs, DDGS, Corn, Digestion, Finishing Diets)
\end{abstract}

\section{INTRODUCTION}

During the production process of corn dry distillers grain with solubles (DDGS), protein, minerals, fat and fiber are concentrated three-fold as co-products when compared with corn. Therefore, corn DDGS contains approximately $30 \%$ crude protein $(\mathrm{CP}, 52 \%$ ruminal undegradable intake protein, UIP) and $11 \%$ fat (NRC, 2000), and often costs less than corn (USDA, 2010). Historically DDGS has primarily been fed to beef cattle, dairy animals include dairy sheep, swine and poultry (Rosentrater, 2012). Even though DDGS should be appropriate as a feed ingredient for sheep, there are limited reports in terms of the effects on digestive function and the energy value of DDGS for this species.

\footnotetext{
* Corresponding Author: Alejandro Plascencia. Tel: +52-686-563 6906 (111), Fax: +52-686-5636907, E-mail: aplas_99@yahoo.com ${ }^{1}$ Veterinary School, University Autonomous of Sinaloa, México.

${ }^{2}$ Department of Animal Science, University of California, Davis, USA.

Submitted Jan. 22, 2013; Accepted Mar. 25, 2013; Revised Apr. 1, 2013
}

The high potential of the nutritional value of DDGS can be useful for replacing dry-rolled (DR) or steam-flaked corn in growing-finishing diets of beef cattle (Klopfenstein, 2008). However, it appeared that the feed value of distillers grains may vary by level of inclusion (Uwituze et al., 2010) and by the type of processing (DR or steam-flaked) of the corn grain that is replaced (May et al., 2009; Luebbe et al., 2012). The optimal responses (daily weight gain and feed efficiency) in feedlot cattle when DDGS has replaced corn grain in finishing diets have been observed with moderate levels (i.e. 20\%) of DDGS inclusion as a replacement of steam-flaked grain (May et al., 2009; Uwituze et al., 2010; Luebbe et al., 2012). Leupp et al. (2009) have reported that replacing DR corn with up to $60 \%$ DDGS in $70 \%$ concentrate diets resulted in no adverse effects on total tract OM digestion in steers, although ruminal OM digestion decreased and microbial production efficiency increased with increasing DDGS. Compared to steers, lambs has a greater ability to effectively utilize DR corn (Theurer, 1986); thus, the associative effects as a result of the 
replacement of DR corn with DDGS can have a different impact on nutrient digestion in fattening lambs. However, very little information is available on the effects of DDGS replacing DR corn on site and the extent of digestion of nutrients and digestible energy (DE) in lambs fed a highenergy diet.

Consequently, the objective of this study was to determine the effects of DDGS supplementation levels replacing $\mathrm{DR}$ corn on digestive function in lambs fed a high-energy DR corn-based diet.

\section{MATERIAL AND METHODS}

\section{Animals, diets and sampling}

The trial was conducted at the Ruminant Metabolism Experimental Unit of the Instituto de Investigaciones en Ciencias Veterinarias of the Universidad Autónoma de Baja California, located $10 \mathrm{~km}$ south of Mexicali City in northwestern México (32 $42^{\prime} 7^{\prime \prime} \mathrm{N}$ and $\left.115^{\circ} 28^{\prime} 6^{\prime \prime} \mathrm{W}\right)$. The area is about $10 \mathrm{~m}$ above sea level, and has Sonoran desert conditions (BWh classification according Köppen). All animal management procedures were conducted within the guidelines of locally-approved techniques for animal use and care (NOM-051-ZOO-1995: humanitarian care of animals during mobilization of animals; NOM-062-ZOO1995: technical specifications for the care and use of laboratory animals. Livestock farms, farms, centres of production, reproduction and breeding, zoos and exhibition hall, must meet the basic principles of animal welfare; NOM-024-ZOO-1995: animal health stipulations and characteristics during transportation.

Four male lambs (Katahdin; average live weight $25.9 \pm 2.9 \mathrm{~kg}$ ) with " $\mathrm{T}$ " type cannulas in the rumen and proximal duodenum (4 $\mathrm{cm}$ from the phyloric sphincter) were used in a $4 \times 4$ Latin square experiment to evaluate the influence of supplemental DDGS levels in the substitution of DR corn on characteristics of digestive function. Four dietary treatments were compared: i) Control (0\% DDGS); ii) $10 \%$ DDGS; iii) $20 \%$ DDGS; and iv) $30 \%$ DDGS. Diets were formulated to be isocaloric but not isonitrogenous, because the protein level increases as the level of DDGS replacing corn in the diet increased (Table 1). Chromic oxide (used as a source of chromium to estimate nutrient flow and coefficient of digestion) was added to the diets. Chromic oxide ( $4 \mathrm{~g} / \mathrm{kg}$ of diet air dry basis) was premixed with minor ingredients (urea and mineral supplement composed of limestone and trace mineral salts) before incorporation into complete mixed diets. White corn was used as source of grain in the form of a commercial blend obtained from Mexico. Corn was prepared by passing whole corn through rollers $(46 \times 61 \mathrm{~cm}$ rolls, 5.5corrugations/cm; Memco, Mills Rolls, Mill Engineering

Table 1. Ingredients and composition of experimental diets fed to lambs (\% of dry matter, DM)

\begin{tabular}{|c|c|c|c|c|}
\hline \multirow{2}{*}{ Item } & \multicolumn{4}{|c|}{ Dried distillers grains plus solubles level (\%) } \\
\hline & 0 & 10 & 20 & 30 \\
\hline \multicolumn{5}{|l|}{ Ingredient composition (\%) } \\
\hline Dry-rolled corn & 74.50 & 64.50 & 54.50 & 44.50 \\
\hline Dried distillers grains with solubles & 0.00 & 10.00 & 20.00 & 30.00 \\
\hline Soybean meal & 5.00 & 5.00 & 5.00 & 5.00 \\
\hline Sudan grass hay & 10.00 & 10.00 & 10.00 & 10.00 \\
\hline Tallow & 1.50 & 1.50 & 1.50 & 1.50 \\
\hline Molasses & 6.10 & 6.10 & 6.10 & 6.10 \\
\hline Chromium oxide & 0.40 & 0.40 & 0.40 & 0.40 \\
\hline Mineral premix ${ }^{1}$ & 2.50 & 2.50 & 2.50 & 2.50 \\
\hline \multicolumn{5}{|l|}{ Chemical composition $^{2}$ (DM basis) } \\
\hline Crude protein $(\%)$ & 10.95 & 12.61 & 13.98 & 15.51 \\
\hline Lipids $(\%)$ & 3.70 & 4.68 & 5.38 & 5.95 \\
\hline $\operatorname{NDF}(\%)$ & 16.04 & 19.75 & 22.55 & 26.12 \\
\hline Gross energy (MJ/kg) & 17.45 & 17.74 & 18.32 & 18.41 \\
\hline \multicolumn{5}{|l|}{ Calculated net energy $^{3}(\mathrm{MJ} / \mathrm{kg})$} \\
\hline Maintenance & 8.66 & 8.66 & 8.66 & 8.66 \\
\hline Gain & 5.90 & 5.90 & 5.90 & 5.90 \\
\hline
\end{tabular}

${ }^{1}$ Mineral premix was composed by $64 \%$ limestone, $20 \% \mathrm{NaCl}$ enriched with trace mineral and $16 \%$ urea. Mineral premix contained $\mathrm{CP}, 50 \%$; Calcium, 28\%; Phosphorous, 0.55\%; Magnesium, 0.58\%; Potassium, 0.65\%; NaCl, 15\%; vitamin A, 1,100 IU/kg; vitamin E, 11 UI/kg.

${ }^{2}$ Dietary composition was determined by analyzing subsamples collected and composited throughout the experiment. Accuracy was ensured by adequate replication with acceptance of mean values that were within $5 \%$ of each other.

${ }^{3}$ Based on tabular net energy (NE) values for individual feed ingredients (NRC, 1985) with the exception of supplemental fat, which was assigned $\mathrm{NE}_{\mathrm{m}}$ and $\mathrm{NE}_{\mathrm{g}}$ values of 25.1 and $19.87 \mathrm{MJ} / \mathrm{kg}$, respectively (Zinn, 1988). 
\& Machinery Co., Oklahoma, CA) and machinery that had been adjusted so that the kernels were broken into a bulk density of $0.70 \mathrm{~kg} / \mathrm{L}$. The forage source of diet (sudangrass hay) was ground in a hammer mill (Bear Cat \#1A-S, Westerns Land and Roller Co., Hastings, NE) with a $3.81 \mathrm{~cm}$ screen, before incorporation into complete mixed diets. The source of DDGS used was a corn DDGS named for its appearance (color) as "Golden" and was obtained in an ethanol production facility with a $0.8 \%$ maximal content of sulfur (Pinal Energy LLC, Maricopa, AZ). All lambs received ad libitum access to the corn-basal diet $(0 \%$ DDGS) for $14 \mathrm{~d}$ before the initiation of the trial. To avoid refusals, feed intake (as feed basis) was restricted to $750 \mathrm{~g} / \mathrm{d}$ (90\% of ad libitum intake of lambs during the 14-d preliminary period). As result to their intake level, the crude protein intake and energy intake (Table 2) meet the requirements for a lamb of $26 \mathrm{~kg} \mathrm{BW}$ has a weight gain of $100 \mathrm{~g} / \mathrm{d}$ (NRC, 2007). Lambs were maintained in individual metabolism crates $(1.2 \times 1.6 \times 0.7 \mathrm{~m})$ in an indoor facility with access to water at all times. Diets were fed in two equal proportions at 08:00 and 20:00 hours daily. Experimental periods consisted of a 17-d diet adjustment period followed by a 4-d collection period. During the collection period, duodenal and fecal samples were taken from all lambs twice daily as follows: $d$ 1, 07:50 and 13:50 h; d 2, 09:00 and 15:00 h; d 3, 10:50 and 16:50 h; and d 4, 12:00 and 18:00 h. Individual samples consisted of $150 \mathrm{ml}$ duodenal chyme and total fecal material. Samples from each lamb and within each collection period were composited for analysis. During the final day of each collection period, a ruminal sample was obtained from each lamb $4 \mathrm{~h}$ after feeding via the ruminal cannula. Ruminal fluid was taken from the ruminal ventral sac using tygon tubing (i.d. $0.95 \mathrm{~cm}$; USP Lima, Ohio) adapted to a $100 \mathrm{ml}$ syringe (Medical plastic appliance, Jiangzu, China), and the $\mathrm{pH}$ was determined (Orion 261S, Fisher Scientific, Pittsburgh, PA) on fresh samples. Upon completion of the trial, approximately $4 \mathrm{~h}$ after feeding a total of $2 \mathrm{~L}$ of ruminal fluid was obtained from all lambs. Total ruminal fluid was composited and poured in a closed jar protected from light and was mixed (1:1) with a saline solution warmed up to 40 to $45^{\circ} \mathrm{C}$ and immediately taken to the laboratory for the isolation of ruminal bacteria via differential centrifugation (Bergen et al., 1968). The microbial isolate served as the purine: $\mathrm{N}$ reference for the estimation of microbial nitrogen ( $\mathrm{MN}$ ) contribution to chyme entering the small intestine (Zinn and Owens, 1986).

\section{Sample analysis and calculations}

The bulk density of DR corn and DDGS was measured using a standard bushel tester (OHAUS grain scale Model 8324915, Parssipani, NJ, USA) following the method prescribed by the USDA (1999).

Ingredients (DDGS and DR corn), feed, and duodenal and fecal samples were subjected to the following analysis: Dry matter (DM, oven drying at $105^{\circ} \mathrm{C}$ until no further weight loss; method 930.15, AOAC, 2000); ash (method 942.05; AOAC, 2000), Kjeldahl nitrogen (method 984.13; AOAC, 2000); neutral detergent fiber (NDF; Van Soest et al., 1991, corrected for NDF-ash) incorporating heat stable $\alpha$-amylase (Ankom Technology, Macedon, NY) at $1 \mathrm{ml}$ per $100 \mathrm{ml}$ of NDF solution (Midland Scientific, Omaha, NE); lipids (acid chloroform-methanol extraction; Zinn, 1994); chromic oxide (Hill and Anderson, 1958); and starch (Zinn, 1990). In addition, gross energy (GE, using the adiabatic bomb model 1271; Parr Instrument Co., Moline, IL. USA) was determined for feed and fecal samples. Ammonia $\mathrm{N}$ (method 941.04; AOAC, 2000) and purines (Zinn and Owens, 1986) were determined in duodenal samples. Organic matter (OM) of feed, duodenal, and fecal samples was determined by difference between DM and ash content. Microbial $\mathrm{OM}$ and $\mathrm{N}$ leaving the abomasum were calculated using purines as a microbial marker (Zinn and Owens, 1986). Organic matter that had fermented in the rumen was considered equal to OM intake minus the difference between the amount of total OM reaching the duodenum and the microbial OM reaching the duodenum. Feed $\mathrm{N}$ escape into the small intestine was considered equal

Table 2. Composition and density of corn dried distillers grains with solubles (DDGS) and dry-rolled corn (DRC) determined by analyses and corresponding tabular values (NRC, 2007)

\begin{tabular}{lcccc}
\hline Item & DDGS & DRC & DDGS & $\begin{array}{c}\text { DRC } \\
\text { (NRC, 2007) }\end{array}$ \\
\hline DM (\%) ${ }^{1}$ & 94.2 & 91.4 & 90.0 & 88.0 \\
CP $(\%)^{2}$ & 26.3 & 9.1 & 29.0 & 9.0 \\
NDF $(\%)^{3}$ & 42.7 & 10.3 & 43.0 & 9.0 \\
Starch (\%) & 4.3 & 69.4 & - & - \\
Lipids (\%) & 9.0 & 3.6 & 10.6 & 4.3 \\
Ash (\%) & 5.6 & 1.7 & 6.0 & 2.0 \\
Gross energy (MJ/kg) & 20.38 & 17.41 & - & - \\
Density (g/L) & 454 & 702 & - & - \\
\hline
\end{tabular}


to total $\mathrm{N}$ leaving the abomasum minus ammonia- $\mathrm{N}$ and $\mathrm{MN}$ and, thus, included any endogenous contributions.

\section{Statistical design and analysis}

The experimental design for this study was a $4 \times 4$ Latin square. Statistical data were analyzed using the MIXED procedure of SAS (2004). Fixed effects consisted of treatments, and random effects consisted of lambs and period. The statistical model for the trial was as follows:

$$
Y_{i j k}=\mu+L_{i}+P_{j}+T_{k}+E_{i j k}
$$

where: $Y_{i j k}$ is the response variable, $\mu$ is the common experimental effect, $L_{i}$ is the lamb effect, $P_{j}$ is the period effect, $T_{k}$ is the treatment effect and $E_{i j k}$ is the residual error. Treatment effects were tested for the following orthogonal components: i) linear effect of DDGS level; ii) quadratic effect of DDGS level; and iii) cubic effect of DDGS level. Coefficients for polynomial contrasts (linear, quadratic and cubic effects of DDGS level) with equal spacing (0, 10, 20 and 30\%) were determined according to SAS (2004). Contrasts were considered significant when the $\mathrm{p}$-value was $\mathrm{p} \leq 0.05$, and as a tendency approaching significance with a $\mathrm{p}$-value of $\mathrm{p} \leq 0.10$.

\section{RESULTS AND DISCUSSION}

\section{Physical and chemical characteristics of DDGS and replaced corn}

The physicochemical composition of DDGS and corn used in the trial and their relative values according to the NRC (2007) are shown in Table 2. The bulk density of DDGS obtained here corresponds closely to the average bulk density (bulk density varied between 0.389 and 0.502 $\mathrm{kg} / \mathrm{L}$ ) reported previously by Rosentrater (2006). While that bulk density of DR white corn was $40 \%$ greater than that reported by Plascencia et al. (2011); thus, there was greater coarse-processing of the corn used in the current study. The nutrient composition of white corn used in the present experiment was consistent with previous reports (Sánchez et al., 2007; Plascencia et al., 2011). Compared to the values assigned to DDGS by the NRC (2007), the relative values of CP, NDF, lipids and ash were $0.90,0.99,0.85$, and 0.93 , respectively. According to the NRC (2007), the main constituent is the NDF, followed by the $\mathrm{CP}$, although this proportion can be changed by the quantity of solubles added during the process (Kim et al., 2008). As a result, much of the variation in the composition of DDGS can be attributed to plant-to-plant differences in the proportions of distillers solubles added during processing (Spiehs et al., 2002; Kim et al., 2008). Due to the greater lipids content of DDGS than that of the DR corn, and compared to the control diet, increasing the DDGS level in the diet increased (linear component; $\mathrm{p}<0.01$, Table 3 ) the lipid intake by 7.0, 11.7 and $15.8 \mathrm{~g} / \mathrm{d}$ to 10,20 and $30 \%$ DDGS levels, respectively. These values represent a concentration of $8.8 \%$ of the total lipids in DDGS and correspond closely to the total lipids determined by analysis (Table 2) and those reported in DDGS previously (NRC, 2000; Srinivasan et al., 2005; Leupp et al., 2009; Berger and Singh, 2010). The average ash content was very similar compared to the results obtained by Spiehs et al. (2002) and Belyea et al. (2004) but was nearly $50 \%$ lower than the average obtained by Bhadra et al. (2007).

\section{Characteristics of ruminal $\mathrm{pH}$ and site and extent of digestion}

The treatment effects on ruminal $\mathrm{pH}$ and site and extent of digestion are shown in Table 3. The ruminal $\mathrm{pH}$ (sampling $4 \mathrm{~h}$ postpandrium) averaged $6.20 \pm 0.29$, and was not affected $(\mathrm{p} \geq 0.15)$ by treatment, even though the starch intake decreased (Table 3; linear component, $\mathrm{p}<0.01$ ) with greater dietary DDGS levels. This could be due to the potential acidity of DDGS, which came from $\mathrm{H}_{2} \mathrm{SO}_{4}$, a standard treatment in the ethanol production industry (McAloon et al., 2000). In this sense, Felix and Loerch (2011) reported that feeding DDGS (with S content of $0.74 \%)$ at greater inclusions $(60 \%)$ reduced ruminal $\mathrm{pH}$ in cattle. However, similar to our results, previous studies reported no differences in ruminal $\mathrm{pH}$ when $20 \%$ (Peter et al., 2000) or $40 \%$ (Ham et al., 1994) DDGS was included in finishing diets to steers. In contrast, Leupp et al. (2009) observed a linear increase in ruminal $\mathrm{pH}$ as DDGS level increased from 15 to $60 \%$ in the substitution of DR corn.

Even when DM intake was very similar $(\mathrm{p} \geq 0.79)$ among treatments, as a result of different chemical composition among DR and DDGS treatments (Table 2), replacing DR corn with DDGS increased (linear, $\mathrm{p}<0.01$ ) NDF, lipids and $\mathrm{N}$ intakes and decreased (linear, $\mathrm{p}<0.01$ ) the starch intake.

Substitution of DR corn with DDGS did not influence ruminal, post-ruminal or the apparent total tract digestion of starch averaging $87.2 \pm 2.8,90.4 \pm 3.9$ and $98.7 \pm 0.6 \%$ to ruminal, post-ruminal and total tract digestion, respectively. Those starch digestion values are in closely agreement with those observed to lambs fed a DR corn based finishing diet (Green et al., 1987; Larson et al., 1993; Ortega-Cerrilla and Mendoza, 2003). Previous studies (May et al., 2008; Corrigan et al., 2009) which were conducted with steers, reported that the substitution of DR corn with DDGS did not influence site or extent digestion of starch. Starch digestion in steers is not greatly affected by starch intake over a range of 1 to $5 \mathrm{~kg} / \mathrm{d}$ (approximately 2.5 to $12.5 \mathrm{~g}$ of starch $/ \mathrm{kg}$ of BW, Huntington et al., 2006). In the present study, the range of starch intake was 9.1 to $122 \mathrm{~g}$ of starch $/ \mathrm{kg}$ BW. Therefore, the absence of effects with DDGS substitution on starch disappearance in the present study is expected. 
Table 3. Effects of replacing dry-rolled corn with increasing levels of corn dried distillers grains with solubles (DDGS) on characteristics of digestion

\begin{tabular}{|c|c|c|c|c|c|c|c|c|}
\hline \multirow{2}{*}{ Item } & \multicolumn{4}{|c|}{ DDGS in diet } & \multirow{2}{*}{ SEM $^{1}$} & \multicolumn{3}{|c|}{ Contrast p-value } \\
\hline & $0 \%$ & $10 \%$ & $20 \%$ & $30 \%$ & & Linear & Quadratic & Cubic \\
\hline Ruminal $\mathrm{pH}$ & 6.08 & 6.15 & 6.25 & 6.33 & 0.11 & 0.15 & 0.99 & 0.92 \\
\hline \multicolumn{9}{|l|}{ Intake (g/d) } \\
\hline $\mathrm{DM}^{2}$ & 679 & 685 & 684 & 689 & 23 & 0.79 & 0.98 & 0.91 \\
\hline $\mathrm{OM}^{3}$ & 634 & 641 & 639 & 646 & 21 & 0.74 & 0.99 & 0.87 \\
\hline $\mathrm{NDF}^{4}$ & $109^{\mathrm{a}}$ & $135^{\mathrm{b}}$ & $154^{\mathrm{c}}$ & $180^{\mathrm{d}}$ & 4 & $<0.01$ & 0.95 & 0.49 \\
\hline Starch & $319^{a}$ & $272^{\mathrm{b}}$ & $250^{\mathrm{bc}}$ & $236^{\mathrm{c}}$ & 9.9 & $<0.01$ & 0.15 & 0.75 \\
\hline $\mathrm{N}^{5}$ & $11.9^{\mathrm{a}}$ & $13.8^{\mathrm{ab}}$ & $15.3^{\mathrm{b}}$ & $17.1^{\mathrm{c}}$ & 0.44 & $<0.01$ & 0.83 & 0.72 \\
\hline Lipids & $24.4^{\mathrm{a}}$ & $35.6^{\mathrm{b}}$ & $38.7^{\mathrm{bc}}$ & $40.9^{c}$ & 1.1 & $<0.01$ & 0.06 & 0.19 \\
\hline $\mathrm{GE}(\mathrm{MJ} / \mathrm{d})^{6}$ & 11.8 & 12.1 & 12.5 & 12.7 & 0.40 & 0.17 & 0.87 & 0.86 \\
\hline \multicolumn{9}{|c|}{ Flow to duodenum $(\mathrm{g} / \mathrm{d})$} \\
\hline $\mathrm{OM}$ & 351 & 379 & 382 & 393 & 16 & 0.13 & 0.64 & 0.68 \\
\hline $\mathrm{NDF}$ & $67 \mathrm{a}$ & $64^{\mathrm{a}}$ & $77^{\mathrm{a}}$ & $102^{\mathrm{b}}$ & 4.5 & $<0.01$ & 0.02 & 0.83 \\
\hline Starch & 38 & 36 & 32 & 31 & 5.2 & 0.30 & 0.93 & 0.93 \\
\hline $\mathrm{N}$ & 14.6 & 15.6 & 16.2 & 17.3 & 0.92 & 0.07 & 0.93 & 0.83 \\
\hline Nonammonia $\mathrm{N}$ & 13.9 & 14.8 & 15.4 & 16.4 & 0.86 & 0.08 & 0.99 & 0.86 \\
\hline $\mathrm{MN}^{7}$ & 8.26 & 8.67 & 8.41 & 7.63 & 0.96 & 0.63 & 0.56 & 0.97 \\
\hline Feed N & $5.61^{\mathrm{a}}$ & $6.15^{\mathrm{a}}$ & $7.00^{\mathrm{a}}$ & $8.73^{\mathrm{b}}$ & 0.47 & $<0.01$ & 0.25 & 0.79 \\
\hline Lipids & $29.8^{\mathrm{a}}$ & $37.2 b$ & $44.5^{\mathrm{b}}$ & $46.6^{\mathrm{b}}$ & 3.3 & 0.02 & 0.18 & 0.55 \\
\hline \multicolumn{9}{|l|}{ Ruminal digestion (\%) } \\
\hline $\mathrm{OM}$ & $57.5^{\mathrm{a}}$ & $54.4^{\mathrm{ab}}$ & $53.4^{\mathrm{bc}}$ & $50.8^{\mathrm{c}}$ & 0.9 & $<0.01$ & 0.83 & 0.41 \\
\hline NDF & $38.5^{\mathrm{a}}$ & $52.2^{\mathrm{b}}$ & $49.7^{\mathrm{b}}$ & $43.2^{\mathrm{ab}}$ & 2.7 & 0.38 & $<0.01$ & 0.37 \\
\hline Starch & 88.2 & 86.9 & 87.1 & 87.0 & 1.7 & 0.66 & 0.75 & 0.83 \\
\hline Feed N & 52.8 & 55.7 & 54.3 & 48.7 & 2.9 & 0.36 & 0.20 & 0.98 \\
\hline Microbial efficiency $^{8}$ & 23.3 & 22.9 & 21.6 & 19.4 & 1.9 & 0.17 & 0.65 & 0.98 \\
\hline N efficiency ${ }^{9}$ & 1.16 & 1.08 & 1.00 & 0.96 & 0.05 & 0.02 & 0.58 & 0.92 \\
\hline \multicolumn{9}{|c|}{ Postruminal digestion (\%) leaving abomasums } \\
\hline $\mathrm{OM}$ & 66.6 & 65.7 & 65.3 & 62.6 & 2.1 & 0.22 & 0.68 & 0.77 \\
\hline $\mathrm{NDF}$ & $19.2^{\mathrm{ab}}$ & $9.7^{\mathrm{a}}$ & $14.3^{\mathrm{a}}$ & $27.8^{\mathrm{b}}$ & 2.9 & 0.06 & 0.01 & 0.69 \\
\hline Starch & 90.7 & 90.7 & 90.8 & 89.8 & 1.7 & 0.74 & 0.88 & 0.79 \\
\hline $\mathrm{N}$ & 77.0 & 77.2 & 76.1 & 77.1 & 1.2 & 0.86 & 0.69 & 0.56 \\
\hline Lipids & 80.5 & 78.7 & 79.9 & 79.2 & 2.7 & 0.88 & 0.32 & 0.72 \\
\hline \multicolumn{9}{|l|}{ Fecal excretion $(\mathrm{g} / \mathrm{d})$} \\
\hline DM & $142^{\mathrm{a}}$ & $154^{\mathrm{ab}}$ & $130^{\mathrm{ab}}$ & $173^{\mathrm{b}}$ & 7.6 & 0.03 & 0.90 & 0.71 \\
\hline $\mathrm{OM}$ & $117^{\mathrm{a}}$ & $130^{\mathrm{ab}}$ & $133^{\mathrm{ab}}$ & $147^{\mathrm{b}}$ & 8.3 & 0.04 & 0.95 & 0.60 \\
\hline NDF & $53^{\mathrm{a}}$ & $58^{\mathrm{ab}}$ & $67^{\mathrm{bc}}$ & $74^{\mathrm{c}}$ & 3.7 & $<0.01$ & 0.72 & 0.71 \\
\hline Starch & 3.4 & 3.3 & 3.1 & 3.3 & 0.57 & 0.83 & 0.77 & 0.85 \\
\hline $\mathrm{N}$ & 3.3 & 3.5 & 3.8 & 3.9 & 0.21 & 0.07 & 0.96 & 0.84 \\
\hline Lipids & $5.8^{\mathrm{a}}$ & $7.9^{\mathrm{b}}$ & $8.9^{\mathrm{b}}$ & $9.7^{\mathrm{b}}$ & 1.29 & 0.02 & 0.64 & 0.77 \\
\hline $\mathrm{GE}(\mathrm{MJ} / \mathrm{d})$ & $2.45^{\mathrm{a}}$ & $2.66^{\mathrm{a}}$ & $2.75^{\mathrm{a}}$ & $3.04^{\mathrm{b}}$ & 0.15 & 0.04 & 0.81 & 0.67 \\
\hline \multicolumn{9}{|c|}{ Total-tract digestion (\%) } \\
\hline DM & $78.8^{\mathrm{a}}$ & $77.5^{\mathrm{ab}}$ & $76.7^{\mathrm{ab}}$ & $74.9^{\mathrm{b}}$ & 1.1 & 0.04 & 0.88 & 0.75 \\
\hline $\mathrm{OM}$ & 81.5 & 79.7 & 79.3 & 77.3 & 1.2 & 0.06 & 0.94 & 0.60 \\
\hline $\mathrm{NDF}$ & $51.1^{\mathrm{a}}$ & $57.2^{\mathrm{ab}}$ & $57.1^{\mathrm{ab}}$ & $59.2^{\mathrm{b}}$ & 2.3 & 0.06 & 0.42 & 0.44 \\
\hline Starch & 98.9 & 98.8 & 98.8 & 98.6 & 0.2 & 0.36 & 0.89 & 0.81 \\
\hline $\mathrm{N}$ & 72.0 & 74.4 & 75.4 & 76.9 & 1.3 & 0.04 & 0.74 & 0.79 \\
\hline Lipids & 76.2 & 77.8 & 77.0 & 76.4 & 0.9 & 0.61 & 0.47 & 0.66 \\
\hline $\operatorname{DE}(\%)^{10}$ & 79.3 & 78.0 & 78.0 & 76.1 & 1.0 & 0.08 & 0.79 & 0.55 \\
\hline $\mathrm{DE} \operatorname{diet}(\mathrm{MJ} / \mathrm{kg})$ & 13.8 & 13.8 & 14.3 & 13.9 & 0.21 & 0.37 & 0.53 & 0.25 \\
\hline
\end{tabular}

${ }_{\mathrm{a}, \mathrm{b}, \mathrm{c}}$ Within rows, means followed by different letters are significantly different at $\mathrm{p}<0.05$.

${ }^{1} \mathrm{SEM}=$ Standard error. ${ }^{2} \mathrm{DM}=$ Dry matter. ${ }^{3} \mathrm{OM}=$ Organic matter. ${ }^{4} \mathrm{NDF}=$ Neutral detergent fiber. ${ }^{5} \mathrm{~N}=$ Nitrogen. ${ }^{6} \mathrm{GE}=$ Gross energy.

${ }^{7} \mathrm{MN}=$ Microbial nitrogen. ${ }^{8}$ Microbial efficiency is expressed as duodenal MN, $\mathrm{g} / \mathrm{kg}$ OM fermented in the rumen.

${ }^{9} \mathrm{~N}$ efficiency is expressed as duodenal non-ammonia $\mathrm{N}, \mathrm{g} / \mathrm{g} \mathrm{N}$ intake. ${ }^{10} \mathrm{DE}=$ Digestible energy. 
Ruminal NDF digestion increased (quadratic effect, $\mathrm{p}<0.01)$ with DDGS substitution. DDGS is a source of readily digestible non-forage fiber (Ham et al., 1994) and its fiber particles are very small. Therefore, rumen microbes could degrade easily (Bhadra et al., 2007). However, the replacement of DR corn with increasing levels of DDGS decreased (linear effect, $\mathrm{p}<0.01$ ) the ruminal digestion of OM. This reduction is expected, and is attributable to the relative differences in the ruminal digestion of NDF $(48.3 \%)$ vs starch $(88.2 \%)$, and the ruminal indigestibility of dietary fat itself (Zinn, 1988). Moreover, it is well known that fat has negative effect on ruminal digestion. Therefore, the dose-dependent decrease in NDF digestion among the DDGS treatments $(10,20$ and $30 \%)$ also seems to show negative effect of fat.

There were no treatment effects on the flow of MN into the small intestine $(\mathrm{p} \geq 0.56)$ and ruminal microbial efficiency (flow of MN to the small intestine as a proportion of OM fermented; $\mathrm{p} \geq 0.17$ ). The substitution of DR corn with DDGS tended to increase (linear effect, $p=0.07$ ) the flow of $\mathrm{N}$ to the small intestine. However, the ruminal $\mathrm{N}$ efficiency (flow of non-endogenous $\mathrm{N}$ to the small intestine as a proportion of $\mathrm{N}$ intake) decreased (linear effect, $\mathrm{p}=$ 0.02 ) with increasing DDGS supplementation. Decreased $\mathrm{N}$ efficiency with increasing DDGS-N intake is expected due to the proportional decrease in $\mathrm{MN}$ contribution as a function of $\mathrm{N}$ intake (whereas $\mathrm{MN}$ flow to the small intestine was similar across treatments, its contribution to intestinal $\mathrm{N}$ supply decreased inversely with $\mathrm{N}$ intake). The ruminal digestion of feed $N$ was not affected $(p \geq 0.20)$ by DDGS substitution. Considering the rumen undegradable intake protein (UIP) for DR corn as 55\% (NRC, 1985b), then the value of UIP for DDGS averaged $44 \%$. This value is less than the current tabular value (52\%; NRC, 2000). Prior estimates of UIP for DDGS have ranged from 40 to 70\% (NRC, 2000; Cao et al., 2009; Leupp et al., 2009; Brake et al., 2010; Islas and Soto-Navarro, 2011). High variation in UIP values may be due to the source and method of processing (Gunn et al., 2009; Hersom et al., 2010), and the proportion of solubles returned to grain solid residues in the DDGS mixture (Cao et al., 2009). Gilbery et al. (2006) observed that at least $87 \%$ of the $\mathrm{N}$ in corn distiller solubles was degraded in the rumen.

There were no treatment effects $(\mathrm{p} \geq 0.22)$ on postruminal digestion of $\mathrm{OM}$ and $\mathrm{N}$. However, the post-ruminal digestion of NDF increased (quadratic effect, $\mathrm{p}=0.01$ ), with a maximal level of $30 \%$ of DDGS. This effect may occur as a compensation of digestion of digestible NDF, which generally occurred in the hindgut when ruminal NDF digestion was low (Gressley et al., 2011), or may be due by analytical mistakes in dietary fiber fractions in duodenal samples. Compared to 10 and 20\% DDGS levels, a $30 \%$ DDGS level showed an average numerically decrease of
$15.2 \%$ (Table 3 ) in the value of NDF ruminal digestion.

Post-ruminal lipids digestion was similar $(\mathrm{p} \geq 0.56)$ across treatments, averaging $78.8 \%$. Post-ruminal lipids digestion (LD, \%) is largely a function of total lipid intake (LI) expressed as grams of lipids/kg BW (LD, \% $=83.18$ 4.52LI-0.68 $\mathrm{LI}^{3}$, Zinn, 1994). In the present study, the lipids content of DDGS diets were 4.7, 5.4 and $5.9 \%$ for 10,20 and $30 \%$ DDGS levels, respectively. According to dry matter intakes for DDGS diets (Table 3) and the average BW of lambs $(25.9 \mathrm{~kg})$, the lipid consumptions of the DDGS treatments would equate to $1.24,1.42$, and $1.58 \mathrm{~g} / \mathrm{kg}$ BW, for the 10, 20 and 30\% DDGS diets, respectively. Thus, dietary lipid intake was below of the $1.6 \mathrm{~g} / \mathrm{kg}$ of $\mathrm{BW}$ suggested by Zinn (1994) as being the optimum digestion of lipids.

DDGS levels tended to increase (linear effect, $p=0.06$ ) the total tract NDF digestion. This tendency in the digestion of NDF reflects the increased intake of highly digestible NDF from diets containing DDGS. However, consistent with the results of Corrigan et al. (2009), the level of DDGS substitution for DR corn decreased (linear effect, $\mathrm{p}<0.01$ ) the total tract $\mathrm{OM}$ digestion. As with ruminal digestion, the reduction in total tract $\mathrm{OM}$ digestion was expected, and was largely attributable to relative differences in the total tract digestion of NDF (58\%) versus starch (99\%). Similar to previous reports in which the lipids intake was moderate (i.e. <6\%) (Zinn and Plascencia, 1993; Plascencia et al., 1999; Uwituze et al., 2010), increases on lipid intake increase fecal excretion of lipids $(p=0.02)$ with no differences in lipids total tract digestion. Consistent with Leupp et al. (2009) and Brake et al. (2010), the total tract apparent $\mathrm{N}$ digestion increased (linear effect, $\mathrm{p}=0.04$ ) with the level of DDGS substitution. However, this effect may be more of a function of the increased $\mathrm{N}$ content of the diet brought about by the replacements (Holter and Reid, 1959). Adjusting for metabolic protein fecal loss (NRC, 1985a), the true digestion of protein in the present study averaged $91.8 \%$ that was similar to the average of previous measurements summarized by the NRC (1985a).

Consistent with effects on total tract OM digestion, the level of DDGS substitution for DR corn tended to decrease (linear effect, $p=0.08$ ) the digestibility of GE, however this did not affect $(\mathrm{p}=0.25)$ the dietary $\mathrm{DE}(\mathrm{MJ} / \mathrm{kg})$, reflecting the greater gross energy content of DDGS versus DR corn in the replacements (Table 2).

\section{CONCLUSION}

Under the conditions of the current experiment, it was concluded that DDGS is appropriate for use as a feed ingredient in the finishing diets of lambs. The estimated UIP value of DDGS used in this study (44\%) was less than current tabular estimates (52\%; NRC, 2000). As a result of 
differences in the proportion of starch:NDF content between DDGS and replaced corn, the lower ruminal and total tract digestion of OM in lambs fed DDGS diets was mainly attributable to relative differences in the total tract digestion of NDF versus starch. However, it did not affect dietary $\mathrm{DE}(\mathrm{MJ} / \mathrm{kg})$, reflecting the greater gross energy content of DDGS versus corn in the replacements. Accordingly, the comparative DE value of DDGS, included up to $30 \%$ in the finishing diets of lambs, may be considered similar to the DE value of the DR corn it replaced in the finishing diets fed to lambs. An additional consideration is that the use of DDGS as an alternative feed for fattening lambs depends on the relative price of DDGS and corn.

\section{REFERENCES}

AOAC. 2000. Official methods of analysis, 17th edn. Association of Official Analytical Chemists, Gaithersburg, Maryland.

Belyea, R. L., K. D. Rausch, and M. E. Tumbleson. 2004. Composition of corn and distillers' dried grains with solubles from dry grind ethanol processing. Bioresour. Technol. 94: 293-298.

Bhadra, R., K. Muthukumarappan, and K. A. Rosentrater. 2007. Characterization of chemical and physical properties of distillers dried grain with solubles (DDGS) for value added uses. Paper No. 077009. ASABE Annual International Meeting, Minneapolis, Minnesota.

Bergen, W. G., D. B. Purser, and J. H. Cline. 1968. Effect of ration on the nutritive quality of rumen microbial protein. J. Anim. Sci. 27:1497-1501.

Berger, L., and V. Singh. 2010. Changes and evolution of corn coproducts for beef cattle. J. Anim. Sci. 88: E143-E150.

Brake, D. W., E. C. Titgemeyer, M. L. Jones, and D. E. Anderson. 2010. Effect of nitrogen supplementation on urea kinetics and microbial use of recycled urea in steers consuming corn-based diets. J. Anim. Sci. 88:2729-2740.

Cao, Z. J., J. L. Anderson, and K. F. Kalscheur. 2009. Ruminal degradation and intestinal digestibility of dried or wet distillers grains with increasing concentrations of condensed distillers solubles. J. Anim. Sci. 87:3013-3019.

Corrigan, M. E., G. E. Erickson, T. J. Klopfenstein, M. K. Luebbe, K. J. Vander Pol, N. F. Meyer, C. D. Buckner, S. J. Vanness, and K. J. Hanford. 2009. Effect of corn processing method and corn wet distiller's grains plus solubles inclusion level in finishing steers. J. Anim. Sci. 87:3351-3362.

Felix, T. L., and S. C. Loerch. 2011. Effects of haylage and monensin supplementation on performance, carcass characteristics, and ruminal metabolism of feedlot cattle fed diets containing $60 \%$ dried distillers grains. J. Anim. Sci. 89:2614-2623.

Gilbery, T. C., G. P. Lardy, S. A. Soto-Navarro, M. L. Bauer, and J. S. Caton. 2006. Effects of corn condensed distillers solubles supplementation on ruminal fermentation, digestion, and in situ disappearance in steers consuming low-quality hay. J. Anim. Sci. 84:1468-1480.

Green, D. A., R. A. Stock, F. K. Goedeken and T. J. Klopfenstein.
1987. Energy value of corn wet milling by-product fed for finishing ruminant. J. Anim. Sci. 65:1655-1666.

Gressley, T. F., M. B. Hall, and L. E. Armentano. 2011. Ruminant Nutrition Symposium: Productivity, digestion and health responses to hindgut acidosis in cattle. J. Anim. Sci. 89:11201130.

Gunn, P. J., A. D. Weaver, R. P. Lemenager, D. E. Gerrard, M. C. Claeys, and S. L. Lake. 2009. Effects of dietary fat and crude protein on feedlot performance, carcass characteristics, and meat quality in finishing steers fed differing levels of dried distillers grains with solubles. J. Anim. Sci. 87:2882-2890.

Ham, G. A., R. A. Stock, T. J. Klopfenstein, E. M. Larson, D. H. Shain, and R. P. Huffman. 1994. Wet corn distillers byproducts compared with dry corn distillers grains with solubles as a source of protein and energy for ruminants. J. Anim. Sci. 72: 3246-3257.

Hersom, M. J., D. L. Boss, J. J. Wagner, R. A. Zinn, and M. E. Branine. 2010. Alpharma Beef Cattle Nutrition Symposium: Alternative energy sources for beef cattle finishing diets. J. Anim. Sci. 88 (E. Suppl.):E121-E122.

Hill, F. N., and D. L. Anderson. 1958. Comparison of metabolizable energy and productive determinations with growing chicks. J. Nutr. 64:587-603.

Holter, J. A., and J. T. Reid. 1959. Relationship between the concentrations of crude protein and apparently digestible protein in forages. J. Anim. Sci. 18:1339-1349.

Huntington, G. B., D. L. Harmon, and C. J. Richard. 2006. Alpharma Beef Cattle Nutrition Symposium: Challenging the limits of caloric intake in feedlot cattle sites, rates, and limits of starch digestion and glucose metabolism in growing cattle. J. Anim. Sci. 84:E14-E24.

Islas, A., and S. A. Soto-Navarro. 2011. Effect of supplementation of dried distillers grains with solubles on forage intake and characteristics of digestion of beef heifers grazing small-grain pasture. J. Anim. Sci. 89:1229-1237.

Kim, Y., N. S. Mosier, R. Hendrikson, T. Ezeji, H. Blascheck, B. Dienn, M. Cotta, B. Dale, and M. L. Ladish. 2008. Composition of corn dry-grind ethanol by-products: DDGS, wet cake, and thin stillage. Bioresour. Technol. 99:5165-5176.

Klopfenstein, T. J., G. E. Erickson, and V. R. Bremer. 2008. BoardInvited Review: Use of distillers by-products in the beef cattle feeding industry. J. Anim. Sci. 86:1223-1231.

Larson, M. E., R. A. Stock, T. J. Klopfenstein, M. H. Sindt, and D. H. Shain. 1993. Energy value of hominy feed for finishing ruminants. J. Anim. Sci. 71:1092-1099.

Leupp, J. L., G. P. Lardy, K. K. Karges, M. L. Gibson, and J. S. Caton. 2009. Effects of increasing level of corn distillers dried grains with solubles on intake, digestion, and ruminal fermentation in steers fed seventy percent concentrate diets. J. Anim. Sci. 87:2906-2912.

Luebbe, M. K., J. M. Patterson, K. H. Jenkins, E. K. Buttrey, T. C. Davis, B. E. Clark, F. T. McCollum III, N. A. Cole, and J. C. MacDonald. 2012. Wet distillers grains plus solubles concentration in steam-flaked corn-based diets: Effects on feedlot cattle performance, carcass characteristics, nutrient digestibility, and ruminal fermentation characteristics. J. Anim. Sci. 90:1589-1602.

May, M. L., M. J. Hands, M. J. Quinn, J. O. Wallace, D. D. Reinhardt, L. Murray, and J. S. Drouillard. 2008. Digestibility 
of dried distiller's grains with solubles in steam-flaked or dryrolled corn diets. Kansas State University Beef Cattle Res. Rpt. Progress. 95:80-85.

May, M. L., M. J. Quinn, C. D. Reinhardt, L. Murray, M. L. Gibson, K. K. Karges, and J. S. Drouillard. 2009. Effects of dry-rolled or steam-flaked corn finishing diets with or without twenty-five percent dried distillers grains on ruminal fermentation and apparent total tract digestion. J. Anim. Sci. 87:3630-3638.

McAloon, A., F. Taylor, W. Yee, K. Ibsen, and R. Wooley. 2000. Determining the cost of producing ethanol from cornstarch and lignocellulosic feedstocks. Technical Report (NREL/TP-58028893). NREL, Golden, Colorado.

National Research Council. 1985a. Ruminant nitrogen usage. National Academy Press, Washington, DC.

National Research Council. 1985b. Nutrient requirement of sheep. 6th Ed. National Academy Press, Washington, DC.

National Research Council. 2000. Nutrient requirements of beef cattle. 7th Ed. National Academy of Press, Washington, DC.

National Research Council. 2007. Nutrient requirement of small ruminant. Sheep, Goats, Cervids, and New World Camelids. National Academy Press, Washington, DC.

Ortega-Cerrilla, M. and M. G. Mendoza. 2003. Starch digestion and glucose metabolism in the ruminant: A review. Interciencia 28:380-386

Peter, C. M., D. B. Faulkner, N. R. Merchen, D. F. Parrett, T. G. Nash, and J. M. Dahlquist. 2000. The effects of corn milling co-products on growth performance and diet digestibility by beef cattle. J. Anim. Sci. 78:1-6.

Plascencia, A., M. Estrada, and R. A. Zinn. 1999. Influence of free fatty acid content on the feeding value of yellow grease in finishing diets for feedlot cattle. J. Anim. Sci. 77:2603-2609.

Plascencia, A., R. Bermudez, M. Cervantes, L. Corona, H. DavilaRamos, M. A. López-Soto, D. May, N. Torrentera, and R. A. Zinn. 2011. Influence of processing method on comparative digestion of white corn vs. conventional steam-flaked yellow dent corn in finishing diets for feedlot steers. J. Anim. Sci. 89: 136-141.

Plascencia, A., G. Mendoza, C. Vazquez, and R. A. Zinn. 2003 Relationship between body weight and level of fat supplementation on fatty acid digestion in feedlot cattle. J. Anim. Sci. 81:2653-2659.

Rosentrater, K. A. 2006. Some physical properties of distillers dried grains with solubles (DDGS). Appl. Eng. Agr. 22:589595.

Rosentrater, K. A. 2012. Feeding DDGS in other animals. In: Distiller grain, production properties and utilization (Ed. K. Lui, and K. A. Rosentrater). CRC Press, Boca Raton, Florida. pp. 391-397.
SAS Institute Inc. 2004. SAS/STAT user's guide: Version 9.1. SAS Institute Inc., Cary, North Caroline.

Spiehs, M., J., M. H. Whitney, and G. C. Shuron. 2002. Nutrient database for distiller's dried grains with solubles produced from new ethanol plants in Minnesota and South Dakota. J. Anim. Sci. 80:2639-2645.

Sánchez, F.C., M. Y. Salinas, G. M. C. Vázquez, C. G. A. Velázquez, and G. N. Aguilar. 2007. Efecto de las prolaminas del grano de maíz (Zea mays L.) sobre la textura de la tortilla. ALAN 57:295-301(In Spanish).

Srinivasan, R., R. A. Moreau, K. D. Rausch, R. L. Belyea, M. E. Tumbleson, and V. Singh. 2005. Separation of fiber from distillers dried grains with solubles (DDGS) using sieving and elutriation. Cereal Chem. 82:528-533.

Theurer, C. B. 1986. Grain processing effects on starch utilization by ruminants. J. Anim. Sci. 63:1649-1662.

USDA.1999. Practical Procedures for Grain Handlers: Inspecting Grain. United States Department of Agriculture - Grain Inspection, Packers, and Stockyards Administration: Washington, DC. Available from URL: http://151.121.3.117/ pubs/primer.pdf (accessed July 13, 2012)

USDA. 2010. Energy balance for the corn ethanol industry. Agricultural Economic Report No. 846. United States Dep. Agric. Washington, DC.

Uwituze, S., G. L. Parsons, M. K. Shelor, B. E. Depenbusch, K. K. Karges, M. L. Gibson C. D. Reinhardt, J. J. Higgins, and J. S. Drouillard. 2010. Evaluation of dried distillers grains and roughage source in steam-flaked corn. J. Anim. Sci. 88:258274

Van Soest, P. J., J. B. Robertson, and B. A. Lewis. 1991. Methods for dietary fiber, neutral detergent fiber, and nonstarch polysaccharides in relation to animal nutrition. J. Dairy Sci. 74:3583-3597.

Zinn, R. A. 1988. Comparative feeding value of supplemental fat in finishing diets for feedlot steers supplemented with and without monensin. J. Anim. Sci. 66:213-227.

Zinn, R. A. 1990. Influence of steaming time on site digestion of flaked corn in steers. J. Anim. Sci. 68:776-781.

Zinn, R. A. 1994. Effects of excessive supplemental fat on feedlot cattle growth performance and digestive function. Prof. Anim. Sci. 10:66-72.

Zinn, R. A., and A. Plascencia. 1993. Interaction of whole cottonseed and supplemental fat on digestive function in cattle. J. Anim. Sci. 71:11-17.

Zinn, R. A., and F. N. Owens. 1986. A rapid procedure for purine measurement and its use for estimating net ruminal protein synthesis. Can. J. Anim. Sci. 66:157-166. 